\title{
Analysis of Valuation risk of overseas mergers and acquisitions of state owned enterprises under current situation
}

\author{
Hui Tang \\ Business School of Jianghan University, Wuhan. China \\ 992334272@qq.com
}

Keywords: Overseas mergers and acquisitions, Valuation risk, financial risk

\begin{abstract}
Overseas mergers and acquisitions in western developed countries started earlier and had a long history of development. Many scholars have made a lots of relevant research.With the development of the economy of China, overseas mergers and acquisitions of state-owned enterprises are more and more frequent. As China's state-owned enterprises have its particularity. M \& A should be carried out according to the actual situation.In today's world, opportunities and challenges coexist, Overseas mergers and acquisitions can help state-owned enterprises to expand their scale, enhance international reputation and create greater economic value, but there are also great risks. The purpose of this paper is to provide some suggestions for risk management.
\end{abstract}

\section{Introduction}

With the trend of economic globalization, The quantity of overseas mergers and acquisitions of Chinese state-owned enterprises increases quickly these years., but from the analysis of a large number of overseas $\mathrm{M} \& \mathrm{~A}$ cases, overseas $\mathrm{M} \& \mathrm{~A}$ risk faced by state-owned enterprises has gradually increased. Valuation risk, in particular, is crucial to the success of mergers and acquisitions.

Overseas mergers and acquisitions in western developed countries started earlier and had a long history of development. Many scholars have made a lots of relevant research.

\subsection{Foreign literature review}

On international investment, the first study was done by American economics professor Hymer ; who analized the overseas investment data of the United States from 1914 to 1956, His conclusion is that the transnational corporations have a great advantages in the capital, technology and other aspects of the management experience, these provide direct power for overseas mergers and acquisitions. James Gleeson analysised financial risk of M\&A in his book "financial risk management", and points out that the enterprises should control risk comprehensively.

\section{2 domestic literature review}

Zhang Biqiong, Li Yue summed up the several Important risks in the process of overseas M\& A of Chinese state-owned enterprises , including the valuation risk before the acquisition of the target company, payment and financing risk in the merger process, integration risk after M\&A. Zheng Shijin carried out a deep study of the weaknesses and improvements of Chinese companies compared to European and American developed countries during the process of the overseas mergers and acquisitions .

\section{The present situation of overseas mergers and acquisitions of Chinese state-owned enterprises}

The overseas M\&A of enterprises can actually be regarded as a kind of investment overseas., 
that also applies to the investment basic law. The investment is reasonable and feasible only because the target enterprises can create a positive NPV for the shareholders.

If the target enterprises can create a positive NPV, then the Next step is to Valuate the target firm . If the acquirer overestimates the value of the target firm, who will pay a high price for the transaction, which will increase the financial burden and debt of the acquirer.

\subsection{The Present situation of overseas mergers and acquisitions of State-owned enterprises}

With accession to the WTO and the rapid economic development of China, more and more Chinese state-owned enterprises start to overseas mergers and acquisitions to expand their own scale. At present, China is in an important period of industrial restructuring and deepening the reform. .As an important part of China's economy, state-owned enterprises are expanding the scale of overseas mergers and acquisitions.

\section{2 the particularity of state-owned enterprises}

\section{(a)Special properties}

There are great differences between the state-owned enterprises and private enterprises .The state-owned enterprises is funded by the national government, or most of its capital is from the national government, therefore, the state-owned enterprises are influenced by the government deeply, and which is not make the profit for sole purpose , who should responsible for the regulation of the national economy.

(b)Special relationship

The position of the state-owned enterprises in the market is different from that of private enterprises. In addition to being regulated by the market, state-owned enterprises are also subjected to government constraints .

(c)Special management

A part of managers of state-owned enterprises in China are selected from Government office, so they are likely to Lack of managerial experience and ability .

\subsection{The reasons for valuation risk of overseas mergers and acquisitions}

\section{(a)Value evaluation method}

There are many ways to evaluate the value of the acquired enterprises, DCF method and net asset method are the two commonly used methods. However, there are some defects in the two methods. Because the reasons for $\mathrm{M} \& \mathrm{~A}$ are different, there will be different considerations about the future cash flow and the future profitability of the acquired company.

(b)Information asymmetry

Overseas enterprises are far away from our country, because of the cultural factors, There are differences in measurement and valuation methods. In order to gain more benefits, the foreign enterprises will whitewash their financial statements, these are difficult to find out.

Due to some restrictions in foreign countries, it is difficult to get to the complete and accurate financial statements, which will bring about the Inaccurate valuation.

(c)The value evaluation system is not established

There are still many shortcomings in current value evaluation system because The value evaluation system of China started relatively late.

\subsection{The special causes of the valuation risk of state-owned enterprises}

Because of the special relationship with the government, the market and the enterprises, the state-owned enterprises also have their unique features In overseas mergers and acquisitions .

(a)Special considerations of particular nature

Because The state-owned enterprises are funded by the national government and responsible for the regulation of the national economy, who will have special considerations when choosing a merger target .They will pay more attention to if the science and technology ahead of the standard or if energy available for our country and so on than Creating benefits, that will make the 
The state-owned enterprises cannot correctly judge the actual value of the target enterprises.

(b)Hysteresis under different mechanisms

For the state-owned enterprises, On the one hand, many of it's decisions are governed by the government, on the one hand it is regulated by the market mechanism, which leads to inaccurate valuations.

(c)Decision errors under special mechanisms

The managers of state-owned enterprises are not only the decision-maker but also the staff of the government. So that they can not make a commercial point of view correctly.

\section{3 conclusion}

\subsection{Alleviating the extent of information asymmetric}

Conducting a thorough investigation.

Give full play to the role of the third party intermediary

The third party agency has a reliable source of information and analytical capabilities that enable it to make reasonable assessments .

Signing a legal agreement

To protect the legitimate rights and interests of both parties in the form of law .

\subsection{Fully understand the limitations of the financial statements of the acquired enterprises}

Appropriate adjustments to the book value of the reported statements of the acquired enterprise

When analyzing the financial statements of the acquired enterprise, it is necessary to make reasonable adjustments to the balance sheet.

Comprehensive understanding of the liabilities of the acquired enterprise

Off balance sheet financing can affect mergers and acquisitions, corporate valuation, and forecasts of future profitability.

\subsection{Choose the right value evaluation method}

Different valuation methods will get different results, and then come to different $\mathrm{M} \&$ a pricing. which should be calculated strictly according to the procedure In order to avoid mistakes.

In today's world, opportunities and challenges coexist, Overseas mergers and acquisitions can help state-owned enterprises to expand their scale, enhance international reputation and create greater economic value, but there are also great risks. The road of the overseas mergers and acquisitions of state-owned enterprises is still very long and there are many improvements to be made.Only by constant exploration and progress can chinese state-owned enterprises have a better future.

\section{Acknowledgement}

This paper is supported by the construction of "economic and industrial integration management of Urban Agglomeration", which is the dominant characteristic discipline group of Hubei provincial universities.

\section{References}

[1] Charles W.L Hill, International Business Competing in the Global Marketplace, Mc Graw Hill Press, 2003

[2] YAOZHONG WANG,ZHIZHONG LIU \& YANG ZHANG, Cross -Border Mergers and Acquisitions: Innovative Capacity and National Economic Security [J], Journal of Economic Policy Reform, 2007: 263 281 
[3] Lutz-Christian Wolff, International M\&A and the Problem of the Effective Date under Chinese Law[J]CCH Hong Kong,2006 